\title{
First-principles Calculations of Interaction between Intense Optical Field and Materials Yoshiyuki MIYAMOTO*1
}

\author{
${ }^{* 1}$ Nanosystem Research Institute, National Institute of Advanced Industrial Science and Technolog (AIST), \\ Central 2 1-1-1 Umezono, Tsukuba 305-8568, Japan
}

(Received December 21, 2010, Accepted May 13, 2011)

\begin{abstract}
Non-equilibrium dynamics induced by the femtosecond laser shot has attracted high attentions in condensed matter community. Interaction between a strong field of light and materials cannot be treated by conventional perturbation theory that assumes both electron wave functions and ionic positions as insensitive to the field. Direct approach for computing real-time propagations of electron wave packet and ionic positions under presence of strong optical field is one of promising solutions. In this review, I present theoretical approaches based on the time-dependent density functional theory and show some examples of ultra-fast dynamics in materials induced by the femtosecond laser shots: exfoliation of graphene layer from graphite and photochemical reaction of molecules encapsulated inside carbon nanotubes.
\end{abstract}

\section{1. はじめに}

近年盛んになってきているフェムト秒レーザーを利用した 物質構造変化の研究により, 熱平衡状態を前提とした考察で は想像できない現象がみつかりつつある。一方で, 高輝度を 持つ光により誘起される物質内の現象は, 今までの理論でよ く使われる摂動理論による扱いの範囲を越えており, 光の場 のなかの電子の波動関数の時間発展を追いつつ, 同時に起こ る分子動力学を扱うことが必要になってきている.

本解説では, 時間依存密度汎関数理論に基づく第一原理計 算による, 高輝度光による物質の応答を扱った理論的研究の 事例を紹介する.

\section{2. フェムト秒レーザー}

フェムト秒レーザーは, 通常の三角関数的に時間変化する 光の場がパルス圧縮されたもので, 文献1)ではパルス照射時 間 $f s\left(1 f_{s}\right.$ は $10^{-15}$ 秒 $)$ 内でエネルギー密度 $I=4 \times 10^{15} \mathrm{~W} /$ $\mathrm{cm}^{2}$ が達成されている. このエネルギ一密度 $I$ と光の電界強 度 $E$ を関連付ける式 $I=1 / 2 \varepsilon_{0} c E^{2} \quad\left(\varepsilon_{0}\right.$ は真空の誘電率, $c$ は 光速）に当てはめると $E$ はおよそ $17.4 V / A$ という大きな值 になっている. このような強電界が静的にあると, 地上のあ らゆる共有結合は破壊されてしまうが, 当然のことながら静 電場でこのような大きな值を達成することは不可能である.

\section{1 フェムト秒レーザーと物質の相互作用}

フェムト秒レーザー照射により, 非常に短い時間でこのよ うな強電界が発生した場合には, まず電子の運動が誘起され 励起状態に至る. それに伴い原子核の運動が誘起される. 原 子核の運動が顕著になるころには印加電界は十分減衰してい るが，その一方で電子系は励起状態のままである，このよう な状況で, 物質内に誘起されるダイナミクスを理論的に予測 するのは, 今までの密度汎関数理論に基づく第一原理計算の

*1 独立行政法人産業技術総合研究所（干305-8568 茨城県つくば 市梅園 1-1-1 中央第 2)
手法では困難であった。

\section{2 時間依存密度半関数理論による高輝度光の扱い}

1984年に Runge とGrossによって発表された論文2)で は, 密度汎関数理論を時間依存する問題に拡張した場合に も, 電子の全電荷分布の時間発展が, 電子系にとっての外場 （この場合は原子核からの場も含む）の時間依存性との間に 1 対 1 対応の関係があることが議論されている.この 1 対 1 対応原理に基づけば, 対象となる物質における電子の基底状 態をまず密度沉関数理論に基づき数值計算しておき, 次に時 間依存密度汎関数理論に基づいて, 電子の波動関数の時間発 展を時間に依存する外場を与えながら計算する事で，フェム ト秒レーザーが引き起こすダイナミクスの数值計算結果は一 意に決まる. 従って数值計算にて, 電子と原子核のダイナミ クスを予測することは可能なはずである.

光の与える場をどう表現するかは, 電磁気学上のゲージの 選択による. 光の波長が長いと近似して, 空間的に一様で時 間変化するベクトルポテンシャル $A$ によって光の場を表現 した場合には, 電子の運動量オペレーター $P$ を $P+e / c A(e$ は電子の電荷素量）と再定義したハミルトニアンによる時間 依存密度汎関数理論の適用により, 電子の波動関数の時間発 展を計算すればよい，文献3)では，そのゲージによる数值計 算により, 絶縁体であるダイアモンド結晶が強い輝度の光照 射のせいで絶縁破壊を起こすことが示されている.

一方, ゲージの選択を変え, 同じく長波長近似により空間 的に一様で時間変化する電場 $E$ によって光の相互作用を記 述することも出来る. (すなわち, 電子の感じるポテンシャ ル項にスカラーポテンシャル項を付け加える.）この場合に は, ハミルトニアンの運動エネルギーの項は変化が無く, ポ テンシャルの項に光の電場によるポテンシャルの項を追加す ることになる. こうすることで, 高輝度の光の電場と原子核 との直接の相互作用も取り込むことも出来るのが，このゲー ジの選択の特長で, 電子励起後の分子動力学を追う場合もこ のゲージの選択がよく行われている. 文献4)では金属クラス ターの，そして文献5）では分子の，フェムト秒レーザー照射 
による分解現象のシミュレーションに成功している.

\section{3 フェムト秒レーザー下での分子動力学計算手法}

文献)にも述べられているが，フェムト秒レーザー光によ り励起された電子状態にて全電荷の空間分布と時間変化が決 まり，その瞬間において原子核にかかる力場をへルマン・フ アイマン力として計算することが出来る.この表式による力 場の計算においては, 電子状態をハミルトニアンの対角化で 決定する場合とは異なり，電子の波動関数が原子核位置にあ らわに依存していないことと, 交差する断熱ポテンシャル面 の平均の断熱ポテンシャル面上の分子動力学計算を行ってい ることが考慮されている。（ただし，電子の波動関数を記述 する基底関数に，原子核位置に依存する局在基底を選択した 場合には，電子の波動関数が原子核位置にあらわに依存して いない，ということを保証できないので，力の計算には細心 の注意が必要である.)

文献 4 ,5)ではクラスターや分子のダイナミクスを計算して いるが，周期境界条件の下での電場 $E$ を用いた計算も可能 である，その場合には，便宜的に真空領域を境界条件の中に 想定し, その真空領域で電場を反転させる近似を採用する. (このようなポテンシャルを，のこぎり歯型ポテンシャル， と呼ぶこともある.）この場合, 分子動力学の数值計算が安 定に進んでいるか否かの判定に必要な，「エネルギー保存則」 を考察する必要がある。この解説では詳細を述べないが, 電 場 $E$ を仮想電荷分布によるクーロン場によるものだと考え ると, 光の場の物質になす仕事を数值計算することが可能で ある. 従って, 時間発展計算の最中の, （物質内部エネル ギー $)+($ 全原子核の運動エネルギー) - (光の場のなす仕事 $)$ を計算し，それが時間によらない保存量である，というのが エネルギー保存則になり ${ }^{6)}$, 数值計算の安定性の目安となる.

実際の数值計算では, 時間に依存する電場 $E$ によるスカ ラーポテンシャル $V_{\text {ext }}(t)$ を本来のポテンシャル $V(r)$ に足 したハミルトニアン $H(t)=T+V(r)+V e x t(t)$ の元での, 電 子の波動関数の時間依存シュレディンガー方程式（時間依 存密度汎関数理論では時間依存コーンシャム方程式）

$$
i d \Psi_{\mathrm{n}} / d t=H(t) \Psi_{n}
$$

を計算する，ここで $T$ は電子の運動エネルギー演算子， $\Psi_{n}$ は電子の波動関数で一体表示となっている. 添え字 $n$ は準 位に対応する.この方程式の数值計算と分子動力学計算を同 時に行う手法の詳細は文献7)で述べられている.

また, 今回紹介する数值計算では行っていないが, 長波長 近似の制限をはずして, 印加電界の空間変調を想定した計算 も可能であり, エバネッセント光と物質の相互作用をシミュ レーションするような場合に適用できると期待される.

\section{3. 応用計算：フェムト秒レーザーによる物質の 構造変化}

本解説では, フェムト秒レーザー照射によるグラファイト 表面における構造変化, ならびにカーボンナノチューブに内 包された塩化水素分子の分解反応の計算事例を紹介する.

今までにも, 理論的にフェムト秒レーザー照射の元での物 質の構造変化は調べられてきた。 それは，例えばレーザー照 射による電子励起により, 電子の占有率が価電子帯のバンド
から伝導体のバンドヘシフトすることを仮定したものであ る、しかしながら，このようなシミュレーションでは電子が 励起状態のまま熱的平衡状態に達しているかのごとく仮定す る必要がある，そこで，励起状態を極端に長く維持したまま の計算にならないように，仮想的に緩和時間をパラメータと して想定し，ボルツマン方程式に基づいた占有率の緩和で励 起の占有率が徐々に基底状態へ戻ることが仮定されている. 一方, 先に述べた電子の時間発展を直接計算する方法では, そのような染意的なシミュレーションを行う必要は無い,

\section{1 グラファイト表面からのグラフェン剥離}

グラファイトの層間距離が, フェムト秒レーザー照射の直 後に変化することが，レーザー照射と電子線回折の組み合わ せによる実験で報告されている8,9)、レーザー照射直後に層 間隔の縮みが見え, やがて間隔が増大するダイナミクスが報 告されている.この実験は, グラファイトのバルクの構造変 化に着目しており, 表面構造の変化を追いかけているのもで はない，では，表面の構造変化はどのようになっているので あろうか?

シミュレーションを実行するに当たり，実験で用いられて いるフェムト秒レーザーのパルス波形に最も似通ったパルス 波形を想定した. 電場の強度の時間変化は Fig. 1 の下段に

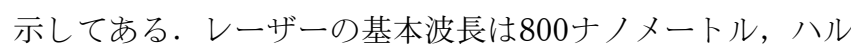
ス半值幅は $45 \mathrm{fs}$ に設定されている．このレーザー強度（最 大で3.7 V/A) においてグラファイト表面が受ける 1 ショッ トあたりのエネルギー密度は $87.9 \mathrm{~mJ} / \mathrm{cm}^{2}$ であることが，第 一原理計算による内部エネルギー上昇でわかっている10). 実験8,9) に出来るだけ近い条件のシミュレーションを行うた めに, レーザー分極は表面に対して垂直となるように設定し た.シミュレーションで得られたグラフェンの分子動力学計 算結果は，レーザー電場が減衰する時刻 $100 \mathrm{fs}$ 以降に表面第 一層のグラフェンがグラファイトより剥がれていくことを示 している. (Fig. 1の上段.)

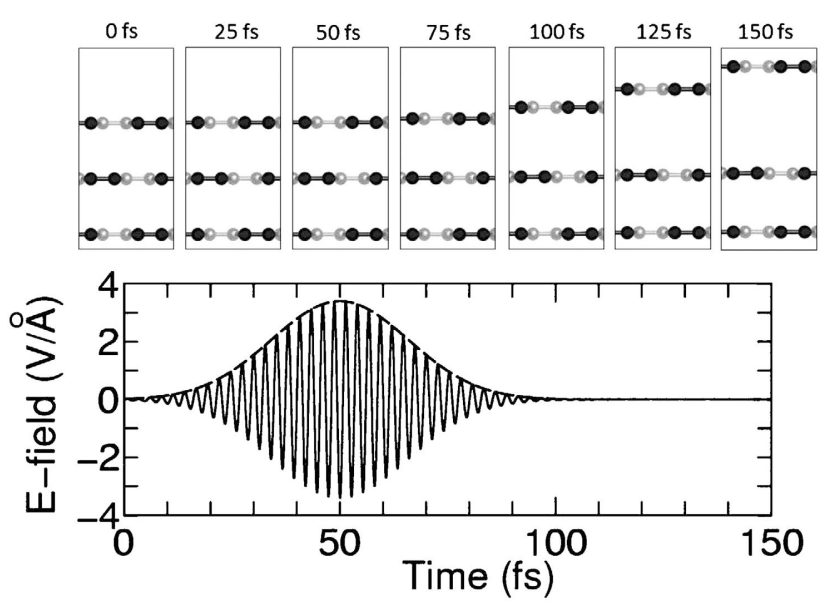

Fig. 1 (Bottom) The time-evolution of the electric field of the femtosecond laser pulse with wave length of $800 \mathrm{~nm}$ and full width of half maximum (FWHM) $45 \mathrm{fs}$. The dotted line indicates the envelope of the pulse shape. (Top) Dynamics of the surface of $\mathrm{AB}-$-stacked graphite. The view is on a plane perpendicular to each graphene sheet. Dark and light gray balls are carbon atoms in- and out-of-the displayed plane. 
(a)

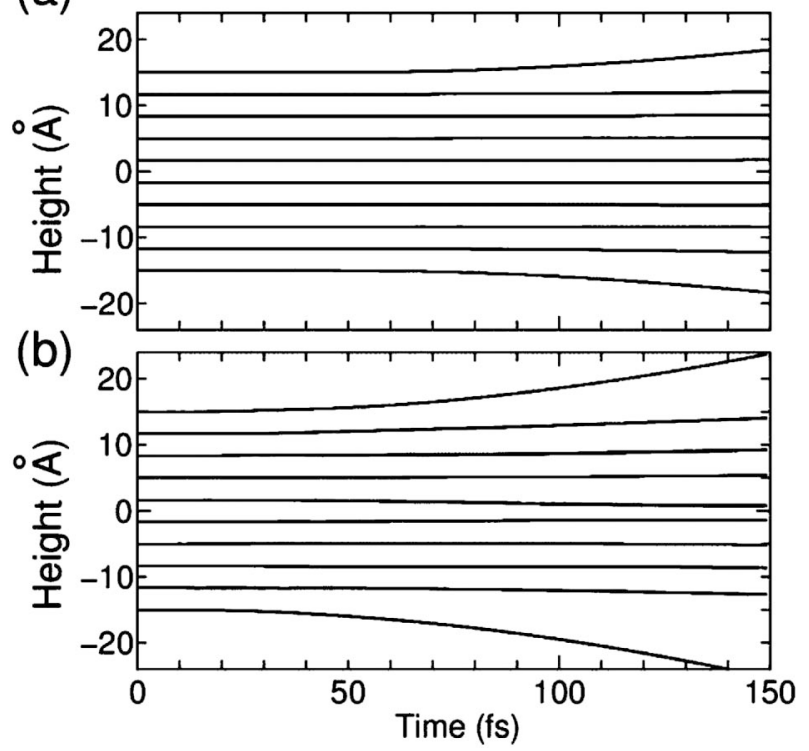

Fig. 2 Time evolution of relative height of each layer of ABstacked graphite slab upon irradiation with the femtosecond laser with (a) FWHM $=45 \mathrm{fs}$, and (b) $10 \mathrm{fs}$.

計算上ではパルスの波形を自在に変化させて, 構造変化の 違いを見ることが容易である．半值幅を $10 \mathrm{fs} に$ 圧縮して同 じ強度 (電界 $E$ が最大で $3.7 \mathrm{~V} / \AA$ ) のパルスを照射した場合, グラファイトに与えるエネルギーは $20 \mathrm{~mJ} / \mathrm{cm}^{2}$ に減少する ものの, 表面のグラフェンが剥がれていく速度はかえって速 いことが計算で解った. Fig. 2の (a) と（b)に，半値幅 $45 \mathrm{fs}$ のパルスによるものと, $10 \mathrm{fs}$ のパルスによるグラファイト 層の各層の高さの時間変化を比較して示す. 数値計算におい て，ユニットセルあたり10層のグラファイト層を仮定し， 周期的境界条件のために表面は上側と下側の 2 箇所にある. Fig. 2(b)に捻いて, 表面層の剥がれの運動が Fig. 2 (a)より 著しく速いのがわかる. 実験に先駆けて, 数值計算だけでグ ラフェンを最も効率よく剥がす条件を探すことが出来るの が，第一原理計算の魅力である.

では，どうして表面第一層だけのグラフェンが都合よく剥 離していくのだろうか. 剥離の際の表面グラフェンに拈ける 原子あたりの運動エネルギーは $1 \mathrm{eV}$ を越えている, 従っ て, 今回の計算結果が密度汎関数理論で問題となっているグ ラファイト層間の引力（数十 $\mathrm{meV}$ のオーダー）を計算する 際の精度のせいであるとは言いがたい、レーザー照射による 電場の浸透を調べてみると, 表面からユニットセルの中心ま で浸透しておりスクリーニングの効果が小さいことがわかっ たので, 表面だけがレーザー励起されているわけではない. (今回の計算ではグラファイト層数は 10 層を想定している.) レーザー照射後の空間電荷分布を丹念に調べてみると, レー ザー照射パルスが减衰するころに, グラファイトより真空領 域へ電子が飛び出していること, それにより表面付近が正に 帯電し, 更にその下層も正に, その更に下層は負に帯電して いることがわかった.このような電荷分布のバランスは, 静 電力的に最表面層の及が基盤から斥力をうけていることを示 唆している.このことは, グラフェン剥離現象が電子の多体
効果に敏感な現象ではなく, クーロン力だけで説明できる と, 結論付けられる.

ここでの更なる疑問は，何故光電子放出により各グラフェ ン層の電荷が非一様に分布するようになるか，である，打そ らく, 各グラフェン層から光電子放出される電子の波束の間 で干渉が抢きているものと思われるが，それを確認するため には数值計算中の波動関数（複素数）を計算の途中でディス クに書き出さなくてはいけないので, 残念ながらディスク容 量を浪費することと, 計算時間に対してディスク I/O 時間 の長い計算となってしまい，実行は容易ではない，

フェムト秒レーザーによるグラフェン剥離現象を実験的に 検証することは非常に興味深い。論文10)を発表した当初か ら，著者に対して実験家からの問い合わせをいただいてお り，フェムト秒レーザーを用いたグラフェン製造・加工に関 する実験の進渉が待たれるところである.

\section{2 カーボンナノチューブ内部の光化学反応}

カーボンナノチューブの中空に物質を内包する実験は早く

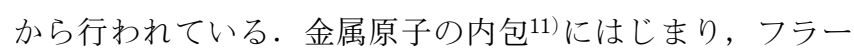
レン12)，有機分子13)など種々の分子を内包することが可能 である. では, 通常の光化学反応を, カーボンナノチューブ に内包した分子に起こさせることは可能であろうか? カーボ ンナノチューブは光のスクリーン効果があり, とくに光の分 極方向がチューブ軸に垂直な条件では, 反転電場の効果が大 きい14). しかしながら, 半導体的性質を持つナノチューブ では, スクリーニングはあるものの有限強度の光電場の浸透 もあり, 入射光の波長がナノチューブの励起エネルギーと共 鳴条件にあれば, 内部で光電場の過渡的な増大も生じること が理論的に示されている15).

今回紹介する計算機実験では, パルス幅 $2 \mathrm{fs}$ と極端に狭 く, 電場の最大強度は $12 \mathrm{~V} / \AA$ を想定した. 導入部で述べた ように，これは実験で達成可能な最大強度よりは遥かに低く 設定された条件である．仮定する基本波長は $800 \mathrm{~nm}$ で，こ の波長では光の振幅を示す波がパルス幅の中に一個入るのが 精一杯で, 電界の振幅も非対称的なものになる. (Fig. 3 参 照のこと）これは, 電界の時間積分が 0 とならない特殊な 設定である.

半導体的カーボンナノチューブ（カイラリティを示すイン デックスは $(8,0))$ にて, 塩化水素分子を内包させた場合 に, 光の電場ベクトルがこのチューブ軸に垂直偏光したパル スを照射する数值計算実験を行った16)。予備的計算にて, 先に述べた最大電場強度 $12 \mathrm{~V} / \AA$ ではカーボンナノチューブ が破壊されないことが確認されている。もしパルスの最大強 度が $13 \mathrm{~V} / \AA$ を越えると $(8,0)$ チューブは, グラフェン片 に分解することも数值計算で分かっている.

Fig. 4 には, 塩化水素分子の分解する様子が示されてい る. 図の水平方向（すなわち, チューブ軸に垂直方向）が光 の電場ベクトルの偏光方向で, Fig. 3 の非対称的な振幅によ り電場ベクトルが Fig. 4 の水平方向の左側に振れる時間が 長い.このパルス印加後直ちに, 塩化水素分子は水素原子と 塩素原子に分解してしまう. 水素原子は最終的に運動エネル ギー $1.9 \mathrm{eV}$ を得る一方で, 塩素原子に与えられる運動エネ ルギーは $0.1 \mathrm{eV}$ 以下である. 原子質量の差（水素 1 に対し 


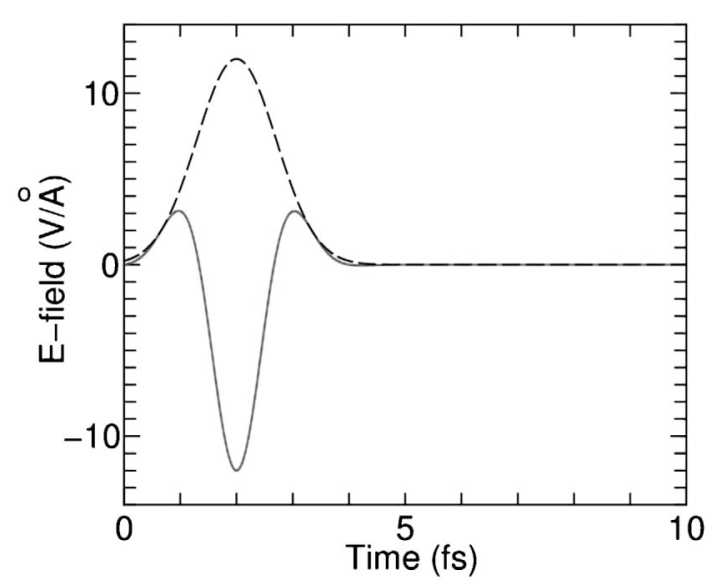

Fig. 3 The time evolution of ultrashort laser shot with wave length of $800 \mathrm{~nm}$ and $\mathrm{FWHM}=2 \mathrm{fs}$. The dotted line indicates the envelope of the pulse shape.

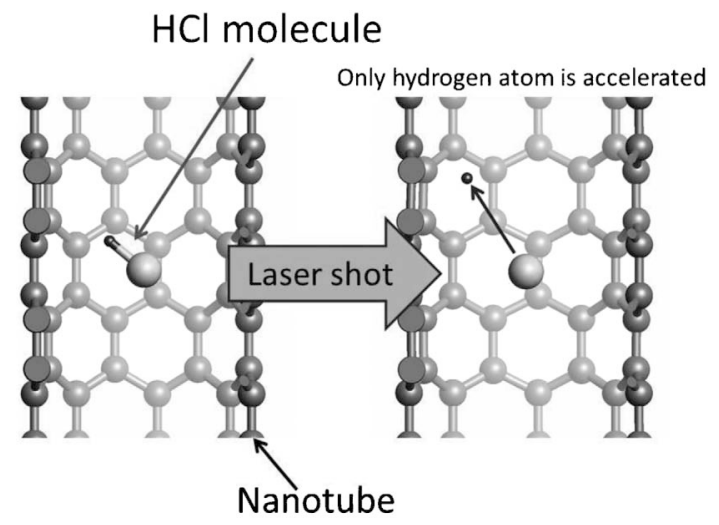

Fig. 4 Snapshots of the molecular dynamics at 0 fs and $16.3 \mathrm{fs}$ of an $\mathrm{HCl}$ molecule encapsulated inside the $(8,0)$ carbon nanotube. Small and large balls are respectively hydrogen and chlorine atoms, and gray balls with middle sizes are carbon atoms.

塩素35.5）を考えると塩素原子は水素原子に比較して静止し ているといってもよい.

な抢，このような分解ダイナミクスは，塩化水素分子の向 きにも依存する．ナノチューブの軸と平行に分子が向いた場 合には，分子の分解は起きずに，大きな振幅で振動する．ま た，Fig. 4 の様な斜めではなく，分子軸がナノチューブの軸 に完全に直交した場合には, 分解して飛び出した水素原子が ナノチューブの内壁で反射され，もとの塩素原子に戻るとい う興味深いダイナミクスが観察された。この際には, ナノチ ューブの壁に原子空孔が形成される. 実際の分子は温度効果 でピコ秒の時定数で回転しているので，レーザーを照射する タイミングをずらした計算を統計的に行うことができれば, 分子分解確率の計算が可能になるが，これは計算コストのか かる計算になる.

着目すべきは, 水素原子だけが高い運動エネルギーを得る
ことで，このような運動エネルギーの非対称な分配が，他の 水素を含む分子の分解反応に扔いても達成されるかどうかは 非常に興味深い。

\section{4. むすびに}

フェムト秒レーザーの照射による物質の合成や改質の研究 は始まったばかりである. 非平衡状態を利用した構造変化 は, 高融点材料の加工手段として魅力がある. その反面, 照 射してみないと何が起こるかわからないことも多い. 1998 年に，パルス波形をコンピューターで変化させながら生成物 をモニターし，上り収量をあげるようにパルス波形にフィー ドバックをかける，という実験が行われた17)。これは, 帰 納的な遺伝的アルゴリズムでパルス波形を変化させるプログ ラムをコンピューターに実行させて, 自動的にパルス波形の 条件出しを行ったものだが, 実験部分を時間依存密度汎関数 理論による計算に置き換えることができれば，実験に先駆け て最適なパルス波形を設計することも夢ではなくなる.

もちろん，一番重要なのは何故その波形なのか，ぞのよう な量子素過程が物質構造変化を支配しているのかを, 人間が 完全に理解することにまちがいない，数值計算を繰り返すだ けでは, まだその域に到達していないことも, 肝に銘じるべ きである。

\section{〔文献〕}

1) Ch. Spielmann, N. H. Burnett, S. Sartania, R. Koppitsch, M. Schlüter, C. Kan, M. Lenzner, P. Wobrauschek and F. Krausz: Science, 278 (1997) 661.

2) E. Runge and E. K. U. Gross: Phys. Rev. Lett, 52 (1984) 997.

3) T. Otobe, M. Yamagiwa, J.-I. Iwata, K. Yabana, T. Nakatsukasa and G. F. Bertsch: Phys. Rev. B, 77 (2008) 165104.

4) A. Castro, M. A. L. Marques, J. A. Alonso, G. F. Bertsch and A. Rubio: Euro. Phys. J. D, 28 (2004) 211.

5) K. Taguchi, J. Haruyama and K. Watanabe: J. Phys. Soc. Jpn., 78 (2009) 094707.

6) Y. Miyamoto and H. Zhang: Phys. Rev. B, 77 (2008) 165123.

7) O. Sugino and Y. Miyamoto: Phys. Rev. B, 59 (1999) 2579; O. Sugino and Y. Miyamoto: Phys. Rev. B, 66 (2002) 089901 (E).

8) F. Carbone, P. Baum, P. Rudolf and A. H. Zewail: Phys. Rev. Lett., 100 (2008) 035501.

9) R. K. Raman, Y. Murooka, C.-Y. Ruan, T. Yang, S. Berber and D. Tománek: Phys. Rev. Lett., 101 (2008) 077401.

10) Y. Miyamoto, H. Zhang and D. Tománek: Phys. Rev. Lett., 104 (2010) 208302.

11) P. M. Ajayan and S. Iijima: Nature (London), 361 (1993) 333.

12) B. W. Smith, M. Monthioux and D. E. Luzzi: Nature (London), 396 (1998) 323.

13) K. Yanagi, Y. Miyata and H. Kataura: Adv. Materials, 18 (2006) 437.

14) H. Ajiki and T. Ando: Physica B, 201 (1994) 349.

15) H. Zhang and Y. Miyamoto: Appl. Phys. Lett., 95 (2009) 053109.

16) Y. Miyamoto, H. Zhang and A. Rubio: Phys. Rev. Lett., 105 (2010) 248301.

17) A. Assion, T. Baumert, M. Bergt, T. Brixner, B. Kiefer, V. Seyfried, M. Strehle and G. Gerber: Science, 282 (1998) 919. 